\title{
Contribution of Ultrasound Strain Elastography to the Differentiation of Benign and Malignant Thyroid Lesions: Randomized Controlled Study
}

\author{
Ultrason Strain-elastografi Tetkikinin Tiroid Nodülleri Benign-Malign Ayrımına \\ Katkısı: Randomize Kontrollü Çalışma
}

\begin{abstract}
Harun Arslan ${ }^{1 \star}$, Zülküf Akdemir ${ }^{2}$, Alpaslan Yavuz ${ }^{1}$, Necat İslamoğlu ${ }^{2}$, Mesut Özgökçe ${ }^{1}$, Hüseyin Akdeniz $^{1}$, Abdussamet Batur ${ }^{1}$, Nazım Bozan ${ }^{3}$, Sebahattin Çelik ${ }^{4}$, Ali Mahir Gündüz ${ }^{1}$

${ }^{1}$ Van Yuzuncu Yil University, Dursun Odabass Medical Center, Department of Radiology Van, Turkey

${ }^{2} V$ an Healt Science, Training and Research Hospital Department of Radiology, Van, Turkey

${ }^{3} V$ an Yuzuncu Yil University, Dursun Odabaşı Medical Center, Department of Otorbinolaryngology, Van, Turkey

${ }^{4}$ Van Yuzuncu Yil University, Dursun Odabaşı Medical Center, Department of General Surgery Van, Turkey
\end{abstract}

\begin{abstract}
Objective: We aimed to investigate the contribution of strain elastosonography to the distinction of benign and malignant thyroid nodules.

Materials and Methods: The retrospective study included 135 patients who were detected with thyroid nodules on ultrasonography and then underwent fineneedle aspiration biopsy (FNAB). Semi-quantitative strain elastographic evaluation was performed and mean strain ratio was calculated for each nodule. The elastograms were classified using the Tsukuba fivepattern visual scoring system. Accordingly, the lesions with scores 1 and 2 were accepted as soft nodules (benign), score 3 as moderately hard nodules, and scores 4 and 5 as hard nodules (malignant). The nodules were divided as benign and malignant depending on the histopathological results. The FNAB results were compared with elasticity scores.
\end{abstract}

Results: The patients included $18(13.3 \%)$ men and 117 $(86.7 \%)$ women. Of the 135 lesions, $113(83.7 \%)$ were benign and $22(16.3 \%)$ were malignant. Strain ratio value was statistically higher in malignant lesions compared to benign lesions $(p<0.01)$. When compared with the histopathological results, elastosonography scoring had a sensitivity of $81.8 \%$, specificity of $89.4 \%$, positive predictive value (PPV) of $96.2 \%$, and negative predictive value (NPV) of $64.7 \%$. However, compared with the strain ratio values, elastosonography scoring had a sensitivity of $77.3 \%$, specificity of $87.6 \%$, PPV of $95.2 \%$, and NPV of $54.8 \%$ at a cutoff point of 4.850 .

Conclusion: Elastosonography is highly effective in the differentiation of benign and malignant lesions.

Key Words: Ultrasound elastography, strain elastography, thyroid nodule

\section{ÖZET}

Amaç: $\mathrm{Bu}$ çalışmamızda strain elastografi ultrason incelemenin tiroit nodüllerinin benign/malign ayrımına katkısını değerlendirmeyi amaçladık.

Gereç ve Yöntemler: Çalışmamıza ultrasonografi ile tiroit nodülü saptanmış ve sonrasında ince-iğne aspirasyon-biyopsisi (İİB) yapilan 135 hasta dahil edildi. Tüm nodüllerin semi-kantitatif strain-elastografik değerlendirmesi yapıldı, ortalama strain ratio oranları hesaplandı. Olgular beş kademeli Tsukuba skorlamasına göre değerlendirilerek skorlara ayrıldı. Skor 1 ve 2 yumuşak nodul (benign), skor 3 orta sertlikte (genellikle benign) ve skor 4 ve 5 sert nodul (malign) olarak siniflandırıldi. Ayrica nodüllerin İIAB histopatolojik sonuçları benign ve malign olarak sınıflandırıldı ve İ̈AB ile elastografi sonucları karşılaştırıldı.

Bulgular: Hastaların 18'i erkek, 117'si kadın idi. Lezyonların patolojik incelemesinde 113 nodül benign iken 22'si malign $(\% 17,5)$ idi. Malign patolojilerde strainratio değeri istatiksel anlamlı olarak benign patolojilerden daha yüksek bulundu $(\mathrm{p}<0,01)$. Lezyonların elastografik skorlama sonuçları histopatolojik bulgular ile karşılaştırıldığında sensivitesi $(\% 81,8), \quad$ spesivisitesi $(\% 89,4)$, pozitif prediktif değeri $(\% 96,2)$, negatif prediktif değeri $(\% 64,7)$ olarak hesaplandi. Strain değerlerine göre malign -benign ayırımı için ROC analizi yapıldığında kesim değeri 4,850 alındığında; sensitivite $\% 77,3$, spesifite $\% 87,6$, pozitif prediktif değeri $\% 95,2$ ve negatif prediktif değeri \% $\% 4,8$ bulundu.

Sonuç: Elastografi skorları ve strain-ratio hesaplamaları da dahil olmak üzere ultrason elastografi tetkiki tiroid nodüllerinin benign-malign ayrımına katkıda bulunabilecek etkili bir görüntüleme yöntemidir

Anahtar Kelimeler: Ultrason elastografi, strain elastografi, tiroid nodülü 


\section{Introduction}

Thyroid nodules have been reported in 33\% of individuals aged $18-65$ years and in $50 \%$ of individuals aged over 65 years $(1,2)$. Although most of these nodules are of benign character, the prevalence of malignancy has been reported as 5 $15 \%$ (3). Thyroid function tests, scintigraphy, and ultrasonography (USG) provide valuable information on malignancy; however, they fail to discriminate benign and malignant lesions. In accordance with the American Thyroid Association Guidelines, no single ultrasonographic method or combinations of methods is efficiently sensitive or specific to detect all malignant nodules (4,5). Therefore, fine-needle aspiration biopsy (FNAB) is essential for the nodules larger than $10 \mathrm{~mm}$ in size and those with doubtful ultrasonographic features (5). FNAB has been shown to be the most credible preoperative diagnostic technique in the detection of malignant thyroid nodules with a sensitivity and specificity of $65-98 \%$ and $72-100 \%$, respectively (6-9).

Elastography is a novel USG-based diagnostic method used for the assessment of tissue elasticity based on external tissue compression. Strain elastography aims at presenting information about the stiffness of the soft tissue surrounding the hard tissue subjected to mechanical pressure through the assessment of the displacement of tissue on the longitudinal plane. Benign thyroid nodules are 1.7 times and the malignant nodules are 5 times stiffer than normal tissue (9). In this study, we aimed to investigate the effectivity of strain elastography in the differentiation of benign and malignant thyroid nodules.

\section{Materials and Methods}

The retrospective study comprised 135 patients including 18 (13.3\%) men and 117 (86.7\%) women with a mean age of 45.6 (range, 18-78) years. All the patients were evaluated by B-mode USG followed by strain elastography prior to FNAB procedure. The nodules with a cystic component and rough calcification were excluded from the study.

The study was confirmed by Van District Training and Research Hospital Nonpharmacological Trials Ethics Committee. An informed consent was obtained from each patient.

B-mode ultrasonography and strain elastography were performed at a single session by an experienced radiologist using Toshiba Aplio 500 Ultrasound System (Toshiba Medical System) with 7-12 $\mathrm{MHz}$ linear transducers. Prior to the procedure, the patient was placed in the supine position. After the centralization of the lesion, rhythmic compression-decompression maneuvers were performed with the transducer perpendicular to the skin, lesion, and neck. The elastograms obtained before and after compression were graded using the Tsukuba five-pattern visual scoring system (Table 1). In this scoring system, scores 1 and 2 indicate a soft nodule (benign), score 3 indicates a moderately hard nodule (Figure 1 ), and scores 4 and 5 indicate a hard nodule (Figure 2).

Fine-needle aspiration biopsy (FNAB) was implemented with a 21 -gauge needle attached to a 10-cc syringe under USG guidance. The smears were fixed in 95\% ethyl alcohol and then stained

Table 1. Tsukuba scoring in thyroid nodules.

\begin{tabular}{lll}
\hline $\begin{array}{l}\text { TSUKUBA } \\
\text { SCORES }\end{array}$ & Strain Elastography Features & $\begin{array}{l}\text { Macroscopic/Histopathological } \\
\text { Features }\end{array}$ \\
\hline SCORE 1 & $\begin{array}{l}\text { Mostly green-coded lesions with equal elasticity } \\
\text { with the surrounding tissue }\end{array}$ & Soft nodule (benign) \\
\hline SCORE 2 & $\begin{array}{l}\text { Lesions with nonhomogeneous elasticity and blue- } \\
\text { green areas }\end{array}$ & Soft nodule (benign) \\
\hline SCORE 3 & $\begin{array}{l}\text { Lesions coded in blue in the center and green in } \\
\text { the surrounding areas }\end{array}$ & Moderately hard (mostly benign) \\
\hline SCORE 4 & $\begin{array}{l}\text { Completely blue lesions with no echogenic halo in } \\
\text { the surrounding tissue }\end{array}$ & Hard nodule (malignant) \\
\hline SCORE 5 & $\begin{array}{l}\text { Completely blue lesions with an echogenic halo in } \\
\text { the surrounding tissue (loss of elasticity in the } \\
\text { surrounding tissue) }\end{array}$ & Hard nodule (malignant) \\
\hline
\end{tabular}

Van Tip Derg Cilt:25, Sayı:1, Ocak/2018 


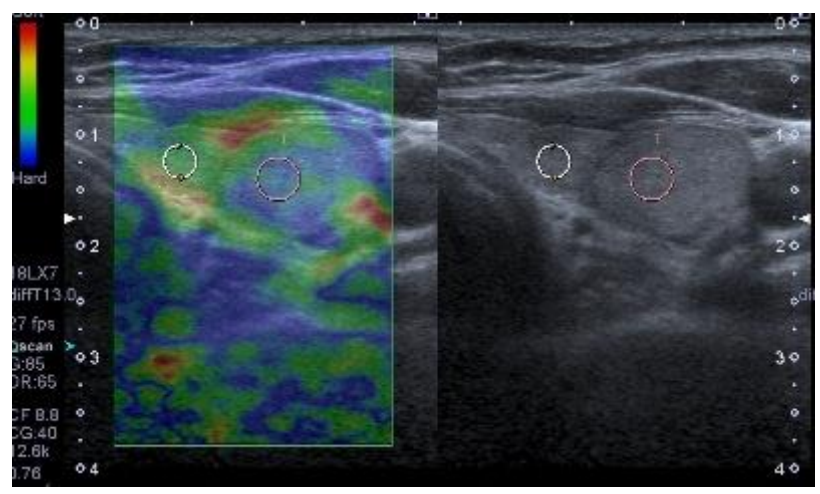

Fig. 1. Real-time ultrasound elastography image reveals elasticity score of 3 .

Table 2. Distribution of Types Nodules According to Elastosonography Scores and Final Histopathological Diagnosis

\begin{tabular}{llll}
\hline Score & Benign & Malignant & Total \\
\hline 1 & $33(29.2)$ & $0(0)$ & 33 \\
2 & $29(25.7)$ & $0(0)$ & 29 \\
3 & $39(34.5)$ & $4(18.2)$ & 43 \\
4 & $12(10.6)$ & 1881.8 & 30 \\
\hline Total & 113 & 22 & 135 \\
\hline
\end{tabular}

with hematoxylin-eosin for pathological assessment. The procedure was repeated in the cases with insufficient material and suspicious results. The lesions were classified as benign and malignant depending on the histopathological results. The FNAB results were compared with the elasticity scores.

Statistical Analysis: Data were analyzed using SPSS 22.0 for Windows (SPSS Inc., Chicago, IL, USA). Frequency tables were obtained for the elasticity scores and descriptive statistics were obtained for patient age, strain ratio value, and lesion size. Differences in mean strain ratio values between the benign and malignant lesions were determined using independent samples $t$-test. Sensitivity and specificity of the elastosonography scoring in the distinction of benign and malignant lesions were calculated. A Receiver Operating Characteristic (ROC) data analysis was implemented to calculate the area under the curve (AUC).

\section{Results}

The study comprised 135 patients that presented to our radiology unit with a thyroid nodule, including $18(13.3 \%)$ men and 117 (86.7\%) women. The nodule was localized in the left lobule in $73(54.1 \%)$ and in the right lobule in 62

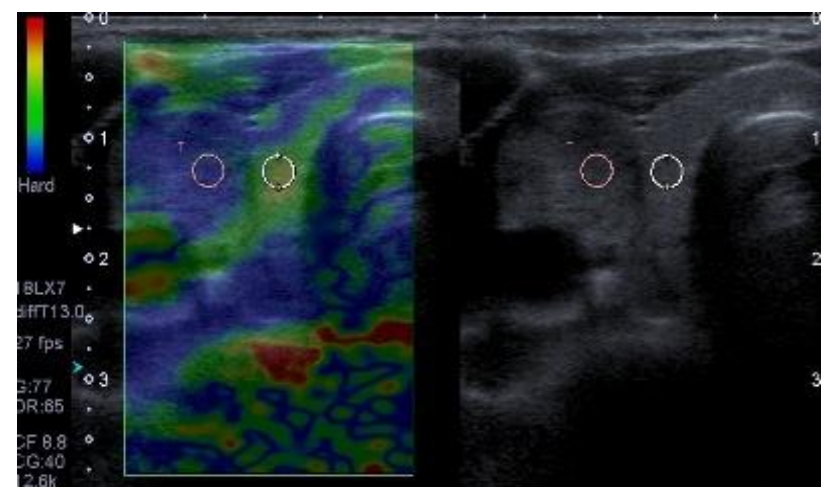

Fig. 2. Real-time ultrasound elastography image reveals elasticity score of 4 .

$(45.9 \%)$ patients. Depending on the pathological results, $113(83.7 \%)$ lesions were classified as benign and $22(16.3 \%)$ as malignant and arithmetic mean values were calculated for patient age, strain ratio value, and lesion size. Mean age was 40.24 years in patients with a benign lesion and 42.38 years in patients with a malignant lesion. Mean lesion size was $16 \mathrm{~mm}(2-34,6)$ in benign lesions and $15 \mathrm{~mm}(10-28,18)$ in malignant lesions. Depending on the elasticity scores, the lesions were classified as follows: elasto-1 $33(29.2 \%)$, elasto-2 29 (25.7\%), elasto-3 benign 39 (34.5\%), elasto-3 malignant $4(18.2 \%)$, elasto-4 benign 12 $(10.6 \%)$, elasto-4 malignant $18(81.8 \%)$, and elasto-5 $0(0 \%)$ (Table 2$)$. Mean strain ratio value was 3.12 in benign lesions and 5.88 in malignant lesions. In the independent-samples $t$-test, no major distinction was found between benign and malignant nodules with regards to mean strain ratio value $(p<0.01)$. Table 3 presents the distribution of benign and malignant lesions and the sensitivity and specificity of elastography scoring in the distinction of benign and malignant lesions. As shown in Table 3, the sensitivity, specificity, positive predictive value (PPV), and negative predictive value (NPV) of elastosonography scoring were $81.8 \%, 89.4 \%$, $96.2 \%$, and $64.7 \%$, respectively. Table 4 presents the sensitivity and specificity of elastography index in the distinction of benign and malignant lesions. As seen in the table, the best cutoff point for malignant lesions was 4.850 in the ROC analysis (Figure 3). At this cutoff point, the sensitivity and specificity of sonoelastography were $95.7 \%$ and $86.7 \%$, respectively. In the ROC analysis, the AUC was 0.994 (95\% CI, 0.983-1, $p<0.001$ ) (Table 5). At the cutoff point of 4.850 , the PPV and NPV of strain ratio values were $99.0 \%$ and $59.5 \%$, respectively. Strain ratio value was statistically higher in malignant lesions in comparison with benign lesions $(p<0.01)$. 
Arslan et al. / Ultrasound Strain Elastography of Thyroid Lesions

Table 3. Sensitivity and Specificity of Elastosonography Scoring for Distinguishing Malignancy

\begin{tabular}{lllllll}
\hline Score & Benign & Malignant & SN $(\%)$ & SP $(\%)$ & PPV $(\%)$ & NPV $(\%)$ \\
\hline $1-3$ & 101 & 4 & 81.8 & 89.4 & 96.2 & 64.7 \\
4 & 12 & 18 & & & & \\
\hline Total & 113 & 22 & & & \\
\hline
\end{tabular}

Table 4. Sensitivity and Specificity of Elastosonography İndex for Distinguishing Malignancy

\begin{tabular}{lllclll}
\hline Index & Benign & Malignant & SN $(\%)$ & SP $(\%)$ & PPV $(\%)$ & NPV (\%) \\
\hline $0-4.850$ & 99 & 5 & 77.3 & 87.6 & 99.0 & 59.5 \\
$4.851-7.90$ & 14 & 17 & & & & \\
\hline
\end{tabular}

RoC Curve

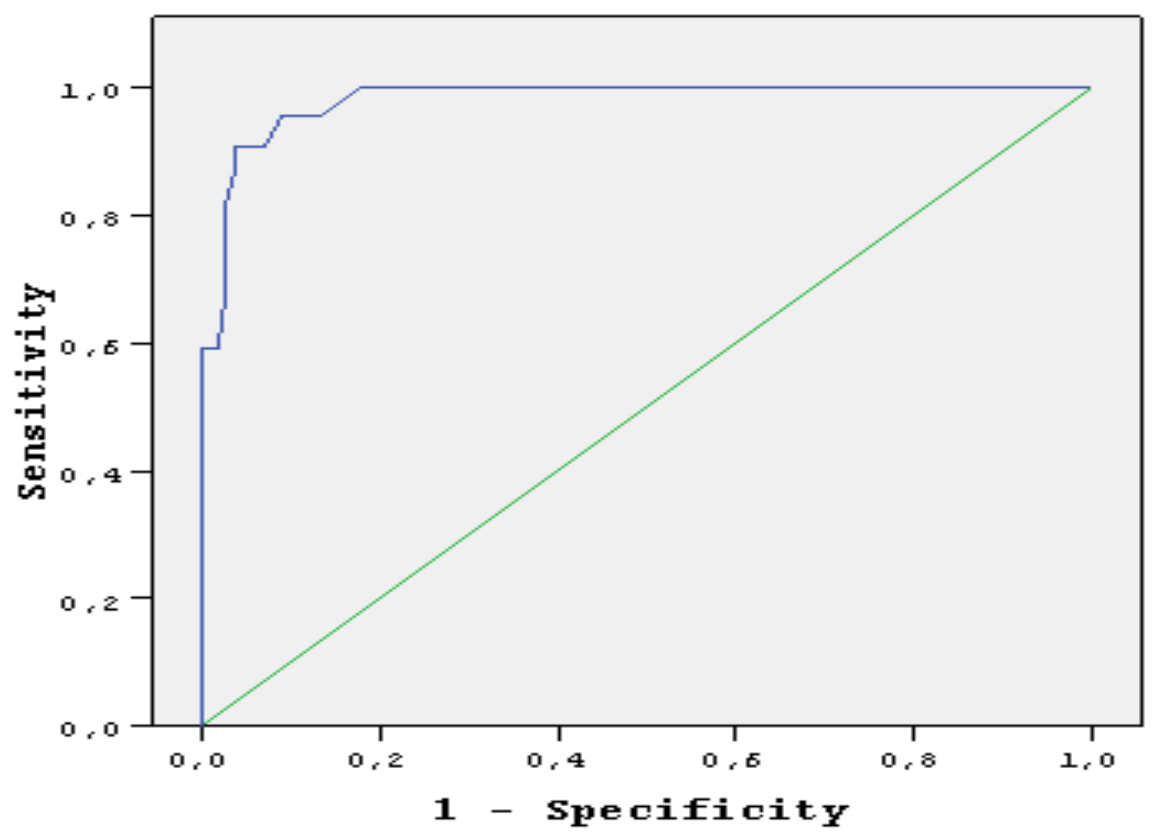

Fig. 3. ROC curve of strain index for distinguishing for malignant from benign nodules.

Tablo 5. AUC of Elastography Scoring and Index

\begin{tabular}{lll}
\hline AUC $(\%)$ & p & $\begin{array}{l}95 \% \text { confidence } \\
\text { interval for AUC }\end{array}$ \\
\hline 98.1 & 0.000001 & {$[0.961-1.001]$} \\
\hline
\end{tabular}

\section{Discussion}

Typical sonographic features of thyroid nodules reported as being suggestive of malignancy include marked hypoechogenicity, nonuniform borders, presence of microcalcifications, a ratio of the lateral to the anterior-posterior diameter of higher than $1 \mathrm{~cm}$, and intranodular vascularity. However, these features usually are not efficiently sensitive or specific to detect all malignant nodules; therefore, FNAB is required in most cases (4). USG has become a popular procedure in the assessment of thyroid nodules. Moreover, the accuracy of USG in the detection of thyroid nodules has become further improved due to the emergence of high-resolution USG devices with high-frequency transducers. As a result of these technological advancements, researchers can obtain better results in the diagnosis of malignant thyroid nodules. Nevertheless, conventional USG does not provide data about the hardness of the nodules. Elastography is a lately advanced technique that allows the evaluation of tissue elasticity (10). This technique is a USG-based technology that provides information on the risk of malignancy by assessing the stiffness of the 
lesion (11,12). Moreover, it is also used for evaluating the mechanical and elastic features of the soft tissue. Pathological changes lead to structure alteration in the lesion, thereby resulting in modification of the elastic features of the tissue. Malignant thyroid nodules, particularly papillary carcinoma, tend to be harder than benign nodules (8). In our study, papillary carcinoma was the most common malignant nodule and both the elastography scores and the strain ratio index were importantly higher in malignant nodules than in benign nodules. However, literature shows that increased stiffness may not be present in all malignant tumors and some benign nodules can have high elasticity scores since the fibrosis within both benign and malignant nodules can rise hardness (9). Similarly, in our study, 4 cases of papillary carcinoma had an elasticity score of 3 and a lesion that was diagnosed as follicular adenoma on FNAB had a score of 4.

Rago et al. (13) evaluated 92 cases and reported the sensitivity and specificity of elastography as $97 \%$ and $100 \%$, respectively. However, the authors indicated that they obtained these high rates since the study group comprised a select population with cytological suspicion or large nodular size. Similarly, Lyshchik et al. (14) assessed 52 patients with thyroid nodules and reported the sensitivity and specificity of elastography as $82 \%$ and $96 \%$, respectively. In that study as well, the study group comprised a select population, most of whom had malignant nodules. Similarly, in our study, the sensitivity and specificity of elastosonography were consistent with those in the literature. In addition, the cutoff point for the elastography scores and the strain ratio values in the distinction of benign and malignant nodules was relatively high, which could also be attributed to the select population in our study.

Strain ratio has been evaluated in numerous studies in the literature. However, none of these studies have reported on a standard cutoff point for the distinction of benign and malignant nodules (15). In one study, a cutoff point of 4.22 resulted in a sensitivity of $81.8 \%$, specificity of $82.9 \%$, and accuracy of $88 \%$ (16), whereas 3.79 was the best cutoff point in another study, with a sensitivity of $97.8 \%$ and specificity of $85.7 \%$ (17). In addition, cutoff points as low as 1.5 and as high as 5 have been suggested in the literature. In our study, the cutoff point of 4.850 yielded a sensitivity of $95.7 \%$ and specificity of $86.7 \%$.

Literature shows that the nodules with calcifications and those localized in the isthmus have been either excluded from some studies (18) or included into some other studies (19). In our study, these nodules were excluded from the study.

Unlütürk et al. (20) suggested that elastography is not superior to grey-scale USG in the prediction of malignancy in thyroid nodules. However, our results indicated that both elastography and strain ratio value are valuable techniques in the detection of malignancy in thyroid nodules.

Our study was limited in several ways. First, sonoelastography is a user-dependent method. Second, the internal features of the lesions shown on sonoelastography (calcification, fibrosis, pure cyst) may lead to misleading evaluations and pitfalls. For this reason, we did not include calcified and pure cystic nodules in our study. Another limitation is that the compression maneuvers performed with the transducer may result in deceptively extreme rigidity, particularly in superficial tissues such as thyroid nodules (21). Therefore, in our study, we performed minimal pressure on the lesions before initiating the palpation cycle. The final limitation could be that we did not use non-user-dependent methods such as shear wave elastography and Acoustic Radiation Force Impulse (ARFI) imaging. However, recent studies indicate that there is no significant difference between elastosonography and these two techniques in terms of sensitivity, specificity, and accuracy (22).

In conclusion, elastosonography is highly effective in the distinction of benign and malignant lesions. Moreover, it can be used as a complementary technique for grey-scale ultrasonography and may reduce the need for fine-needle aspiration biopsy.

Funding: N/A

Conflict of Interest: The authors declare that they have no conflict of interest

\section{References}

1. Reiners C, Wegscheider K, Schicha H, Theissen P, Vaupel R, Wrbitzky R, et al. Prevalence of thyroid disorders in the working population of Germany: ultrasonography screening in 96,278 unselected employees.Thyroid. November 2004, 14(11): 926-932.

2. Howlett DC, Speirs A. The thyroid incidentaloma: ignore or investigate? J Ultrasound Med 2007; 26 (10): 1367-1371.

3. Tumbridge WM, Evered DCR. Hall, Appleton $\mathrm{D}$, Brewis M, Clark F, et al. "The spectrum of thyroid disease in a community: the Whick-ham 
survey. Clin Endocrinol (Oxf) 1977; 7(6): 481493.

4. Lannuccilli JD, Cronan JJ, Monchik JM. Risk for malignancy of thyroid nodules as assessed by sonographic criteria: the need for biopsy. J Ultrasound Med 2004; 23(11): 1455-1464.

5. Cooper DS, Doherty GM, Haugen BR, Kloos RT, Lee SL, Mandel SJ et al. 2009 Revised American Thyroid Association management guidelines for patients with thyroid nodules and differentiated thyroid cancer. Thyroid 2009; 19(11): 1167-1214.

6. Tee YY, Lowe AJ, Brand C.A.R. Judson T. "Fineneedle aspiration may miss a third of allmalignancy in palpable thyroid nodules: a comprehensive literature review," Annals of Surgery 2007; 246(5); 714-720.

7. Fletti S, Durante C, Torlontano M. Nonsurgical approaches to the management of thyroid nodules. Nat Clin Pract Endocrinol Metab 2006; 2(7): 384-394.

8. Baier ND, Hahn PF, Gervais DA, et al. Fineneedle aspiration biopsy of thyroid nodules: experience in a cohort of 944 patients. Am J Roentgenol 2009; 193(4): 1175-1179.

9. Luo S, Kim EH, Dighe M, Kim Y. Thyroid nodule classification using ultrasound elastography via linear discriminant analysis. Ultrasonics 2011; 51(4): 425-431.

10. Sebag F, Vaillant-Lombard J, Berbis J, Griset V, Henry JF, Petit P, et al. Shear wave elastography: a new ultrasound imaging mode fort he differantial diagnosis of benign and malignant thyroid nodules. J Clin Endocrin Metab 2010; 95(12): 5281-5288.

11. Ophir J, Cespedes I, Ponnekanti H, Yazdi Y, Li $\mathrm{X}$. Elastography, aquantitative method for imaging the elasticity of biological tissues.Ultrason Imaging 1991; 13(2): 111-134.

12. Hoyt K, Forsberg F, Ophir J. Analysis of a hybrid spectral strain estimation technique in elastography. Phys Med Biol 2006; 51(9): 197-209.

13. Rago T, Santini F, Scutari M, Pinchera A, Vitti P. Elastography: new developments in ultrasound for predicting malignancy in thyroid nodules. J Clin Endocrinol Metab 2007; 92(8): 2917-2922.

14. Lyshchik A, Higashi T, Asato R, Tanaka S, Ito J, Mai JJ, et al. Thyroid gland tumor diagnosis at US elastography. Radiology 2005; 237(1):202-211.

15. Cantisani V, Maceroni P, D'Andrea V, Patrizi G, Di Segni M, De Vito C,et al. Strain ratio ultrasound elastography increases the accuracy of colour-Doppler ultrasound in the evaluation of Thy-3 nodules. A bi-centre university experience. Eur Radiol 2016; 26(5): 1441-1449.

16. Xing $\mathrm{P}, \mathrm{Wu}$ L, Zhang C, Li S, Liu C, Wu C. Differentiation of benign from malignant thyroid lesions: Calculation of the strain ratio on thyroid sonoelastography. J Ultrasound Med 2011; 30(5): 663-669.

17. Ning CP, Jiang SQ, Zhang T, Sun LT, Liu YJ, Tian JW. The value of strain ratio in differential diagnosis of thyroid solid nodules. Eur J Radiol 2012; 81(2): 286-291.

18. Lippolis PV, Tognini S, Materazzi G, Polini A, Mancini R, Ambrosini CE, et al. Is elastography actually useful in presurgical selection of thyroid nodules with indeterminate cytology? J Clin Endocrinol Metab 2011; 96(11): 1826-1830.

19. Çakal E, Şahin M, Ünsal İÖ, Güngüneş A, Akkaymak E, Özkaya EÇ, et al. Elastography in the differential diagnosis of thyroid nodules. Ultrason Imaging 2015; 37(3): 251-257.

20. Unlütürk U, Erdogan MF, Demir O, Güllü S, Başkal N. Ultrasound-elastography is not superior to gray-scale ultrasound in predicting malignancy in thyroid nodules. Thyroid 2012; 22(10): 1031 1038.

21. Havre RF, Waage JR, Gilja OH, Odegaard SL. Nesje B, "Real-time elastography: strain ratio measurements are influenced by the position of the reference area," Ultraschall in der Medizin. 2011; 33(6); doi: 10.1055/s-00311273247.

22. Bojunga J, Dauth N, Berner C, Meyer G, Holzer $\mathrm{K}$, Voelkl L, et al. Acoustic radiation force impulse imaging for differentiation of thyroid nodules. PLoS One 2012; 7(8): e42735. 